\title{
Technological diversification and new innovators in European regions: evidence from patent data
}

\author{
Carlo Corradini+ \\ Lisa De Propris ${ }^{\circ}$ \\ + Aston Business School \\ ${ }^{\circ}$ Birmingham Business School
}

\begin{abstract}
This paper assesses the impact of regional technological diversification on the emergence of new innovators across EU regions. Integrating analyses from regional economics, economic geography and technological change literatures, we explore the role that the regional embeddedness of actors characterised by diverse technological competencies may have in fostering novel and sustained interactions leading to new technological combinations. In particular, we test whether greater technological diversification improve regional 'combinatorial' opportunities leading to the emergence of new innovators.

The analysis is based on panel data obtained merging regional economic data from Eurostat and patent data from the CRIOS-PATSTAT database over the period 1997-2006, covering 178 regions across ten EU Countries. Accounting for different measures of economic and innovative activity at the NUTS2 level, our findings suggest that the regional co-location of diverse technological competencies contributes to the entry of new innovators, thereby shaping technological change and industry dynamics. Thus, this paper brings to the fore a better understanding of the relationship between regional diversity and technological change.
\end{abstract}

Keywords: technological diversification, innovation, technological entry, patents, spillovers, regions 


\section{Introduction}

The entry of new innovative companies is widely regarded as holding a fundamental role for regional economic growth, sustaining competitiveness and resilience as well as preventing lock-in effects in declining industry life-cycles (Cooke, 2001). At the same time, several studies also emphasize the role played by new innovators in driving and shaping the emergence of new technological trajectories, triggering technological change and new industry dynamics (Nelson \& Winter, 1981; Malerba and Orsenigo, 1999; Breschi et al, 2000). Following contributions from the literature on regional economics and economic geography, it is well understood that the characteristics of the spatial context influence the emergence of new innovators as these rely upon access to ideas and technological opportunities through processes of knowledge spillovers (Rodríguez-Pose and Refolo, 2003; Acs et al, 2009), which are geographically localised (Jaffe et al, 1993; Maurseth and Verspagen, 2002; Moreno et al, 2005; Sonn and Storper, 2008).

Previous studies have explored the competitiveness of territories in relation to two contrasting forces acting upon the dynamics of these knowledge externalities, that is, specialisation as against diversification. Such concepts mirror different processes of knowledge creation with respect to the geographical agglomeration of innovative activities (Beaudry and Schiffauerova, 2009). On the one hand, the vast literature on industrial districts and clusters (Becattini et al, 2008) brought to the fore the benefits of MAR externalities external and agglomeration economies resting on learning and innovation dynamics relying on cumulative, sector specific knowledge externalities (Marshall, 1890; Bellandi, 1996). On the other hand, Jacobian economies emerge when spatial contiguity allows for 'distant' knowledge sets to cross-fertilise leading to novel recombination of ideas. In this sense, externalities stemming from diversity and characterised by inter-industry spillovers are 
argued to generate experimentation and more radical innovation (Jacobs, 1969; Desrochers, 2001, Glaeser et al, 1992).

While empirical research has focused on diversity at the social and sectoral level, little attention has been paid to the relationship between technological diversification and innovation. Yet, an important strand of research in economic geography suggests that regional associative capabilities and untraded interdependencies may play a fundamental role in supporting inter-sectoral technological integration and the creation of new innovative combinations (Storper, 1995; Cooke and Morgan, 1998). Accordingly, as regional co-location of diverse technological knowledge may increase combinative opportunities for connecting distant technological fields, it may play a key role in supporting the presence of 'new' innovators, defined as those firms which innovate for the first time ${ }^{1}$.

This paper contributes to the debate on regional diversity exploring the role of regional embeddedness in creating the conditions for actors characterised by different technological competencies to interact and cross-fertilise, culminating in novel technological combinations and the emergence of new innovators. More specifically, we explore the effect of regional technological diversification and other determinants of regional combinatorial opportunities on firms' technological entry.

Our analysis is based on a panel data set constructed by merging patent data from the CRIOS-PATSTAT database covering the period between 1997 and 2006 with regional economic data at the NUTS2 level from Eurostat for 178 regions across ten European countries, i.e., Austria, Belgium, Germany, Spain, France, Italy, the Netherlands, Portugal, Sweden and the UK. ${ }^{2}$

\footnotetext{
${ }^{1}$ Following the literature on industry dynamics (Malerba and Orsenigo, 1999; Breschi et al, 2000), this phenomenon is referred to as firms' technological entry.

${ }^{2}$ Time and regional dimension of the dataset are based on the information available in the Eurostat database.
} 
The paper is organised as follows. In Section 2, we frame our contribution in the debate on technological diversification and regional embeddedness in relation to regional innovation dynamics. Section 3 describes the data used in the empirical analysis, followed by the model specification and the construction of the main variables of interest. Section 4 presents some stylised facts on innovation activity and technological diversification at the NUTS2 level in the observed regions and a discussion for our main findings. Section 5 concludes.

\section{Literature review and hypotheses}

In the last decades, there has been an increasing interest on the hypothesis that diversity in the industrial composition of regions may foster inter-sectoral knowledge externalities (Jacobs, 1969; Beaudry and Schiffauerova, 2009). Since knowledge is a multidimensional concept, different levels of analysis have captured different aspects of regional diversification, with important implications for the observed phenomenon.

Previous literature has mainly focused on economic diversity expressed in terms of employment per industrial sector. Following this perspective, empirical studies found a positive effect of diversity on economic growth, as well as employment and productivity (Glaeser et al, 1992; Feldman and Audretsch, 1999; Rosenthal and Strange, 2003). More recently, regional economic growth and resilience has been argued to rest on a regional sector make-up characterised by related variety (Frenken et al, 2007; Boschma et al, 2012). Previous research also investigated the importance of socio-cultural diversity for greater regional innovation output (Florida, 2002; Florida and Gates, 2003) as well as new firm formation, suggesting that the diverse background and capabilities of some individuals lead to different 
evaluations of new ideas developing in the local knowledge context, thereby triggering new entrepreneurial activities (Lee et al, 2004; Audretsch et al, 2010).

However, while the interactions generated by socio-economic and cultural diversity can be seen as being based on production capabilities, labour skills and market opportunities, they do not offer a clear representation of the regional technological structure. Industrial sectors and even products are characterised by a wide range of technologies, as illustrated by the multi-technology nature of many corporations (Granstrand, 1998). Similarly, sector size does not reflect the level of technological competencies available (Beaudry and Breschi, 2003). Thus, such interactions do not reflect the combinatorial nature of technological invention and the localised associative capabilities that generate new innovation. Only few recent studies looking at the relationship between diversity and innovation have focused on regional technological diversification, with contrasting results. While some do not find evidence that a diversified technological base is conducive to innovation (Beaudry and Breschi, 2003; Ejermo, 2005), others find that significant diversity in the technological composition of a region may support technological breakthroughs arising from the connection of previously unrelated technologies (Castaldi et al, 2014).

The role of regional technological diversification may be more relevant when considering the patterns of technological change through the formation of new innovative companies. Previous literature underlines the role of combinations in the process of technological innovation (Kogut and Zander, 1992; Arthur, 2007). Combining diverse technologies is a complex process, as searching and connecting ideas from different knowledge sets is often serendipitous whilst requiring repeated interactions and communication (Fleming, 2001). Given that knowledge tends to be sticky and tacit in nature and thereby is mostly embodied in people, such process of knowledge recombination is 
crucially improved by geographical proximity (Maurseth and Verspagen, 2002; Howells, 2002; Moreno et al, 2005).

Seminal contributions within the economic geography debate have emphasised the importance of the spatial dynamics of innovation, introducing a new conceptualisation of innovation based on a process of collective learning occurring within and between firms connecting within the regional milieu (Camagni, 1991; Storper, 1997; Cooke and Morgan, 1998). In this framework, proximity mobilizes interactions across firms embedded in formal and informal regional institutions, shaping the relationships that underpin the transmission of knowledge and ideas through a common knowledge infrastructure (Gregersen and Johnson, 1997; Cooke et al., 1998). These sustained interactions define localised associative capabilities that allow technological competencies dispersed in the economic system to be recombined into new technological knowledge (Storper, 1995; Antonelli, 2000). Hence, when regions are technologically diverse the presence of a wider and heterogeneous pool of actors with different technological competencies may activate processes where diverse knowledge can overlap and cross-fertilise.

Following a Schumpeterian perspective, the exploration of combinative opportunities characterised by novel associations of seemingly unrelated technological domains is usually linked with the presence of new innovating firms continuously disrupting established knowledge competencies (Nelson and Winter, 1982; Malerba and Orsenigo, 1993; Breschi et al, 2000), thus driving and reshaping industries' life-cycle (Schumpeter, 1934; Winter 1984, Klepper, 1996). Accordingly, as higher technological diversification increases regional combinatorial opportunities shaped by inter-industry technology spillovers falling outside learning and technological trajectories of established innovators, it may foster the formation of new innovative companies. To this end, sustained interaction becomes critical, as information and knowledge inherent to technological cross-fertilisation is highly fragmented, 
fluid and not easily assimilated (Storper and Venables, 2004). Thus, regional proximity allows inventors to spontaneously interact, meet and share seemingly unrelated ideas, ensuring new combinations may have the time to incubate and translate into new technological entry.

As the heterogeneity of technological competencies available in the region provides higher combinatorial opportunities that may trigger processes of cross-fertilization across different technologies, thereby increasing the occurrence of novel ideas, regions characterised by a diverse technological endowment can be argued to be more likely to create opportunities for new technological combinations and foster a widening pattern of technological change defined by increasing firms' technological entry.

H1.: Regional technological diversification is positively related to firms' technological entry.

The localised nature of knowledge externalities suggests that other region-specific characteristics may be important elements in the analysis of technological entry. The literature on the patterns of technological change underlines the importance of innovation dynamics, with firms' technological entry being associated with the presence of high technological opportunities (Breschi et al, 2000). High opportunities increase the expected returns of $R \& D$ as well as the flow of new technological knowledge, providing incentives to engage in novel innovative activities (Winter, 1984). Moreover, as the innovation rate in the region increases, technological entry can be reinforced by a widespread presence of knowledge spill-overs that further enhance regional combinative opportunities (Malerba and Orsenigo, 1993; Cooke et al., 1998; Breschi et al, 2000).

Insights from the literature on entrepreneurial activity indicate that traditional measures of economic growth and R\&D employment are relevant determinants of new 
innovative firms (Armington and Acs, 2002). Most importantly, this strand of research underlines the centrality of the cumulated stock of local knowledge, as all residual ideas and knowledge left undeveloped and uncommercialised by incumbent innovators may spill over, generating opportunities for new entrants in the region (Rodríguez-Pose and Refolo, 2003; Acs et al, 2009). Accordingly, the presence of new high-technology firms is higher in regions characterised by a rich stock of knowledge (Audretsch et al, 2006).

Finally, another important source of local knowledge externalities and combinative opportunities is related to the innovation activity of public research centres and universities, whose impact on the technological capacity of firms is mainly associated with the public good nature of the research and the creation of highly skilled human capital (Antonelli, 2000; Anselin et al, 1997). In particular, economic geographers have emphasised the crucial interplay between business, university and the public sector in the triple helix to increase localised associative capabilities and strengthen the regional system of innovation (Cooke and Morgan, 1998; Cooke et al., 1998). This works through systemic learning processes and network effects that are particularly relevant for small high-technology companies (Etzkowitz, 2008; Audretsch and Vivarelli, 1996; Cooke, 2002; Rodríguez-Pose and Refolo, 2003).

Building on these arguments, regions with a dynamic innovation activity characterised by high levels of technological opportunities and a rich and dense cumulated knowledge base can be seen as better suited to enable knowledge spillovers and combinatorial processes that may lead to firms' technological entry. Accordingly, our second hypothesis is the following:

H2: Regional technological opportunities and accumulated knowledge exert a positive effect on the rate of firms' technological entry in the region. 


\section{Data and model specification}

\subsection{Data}

The analysis presented here is based on patent data and regional economic statistics at the NUTS2 level for ten EU countries, i.e.: Austria, Belgium, Germany, Spain, France, Italy, the Netherlands, Portugal, Sweden and the UK. Because of constrains in the socio-economic data available at the regional level from Eurostat, which include information on GDP, employment in high-technology sectors and population density, we focus our analysis on patent applications whose priority date ${ }^{3}$ is between 1997 and 2006 included. The resulting dataset presents 422340 patent applications by firms and public research organisations. NUTS2 regions in the ten countries are 178.

The patent data used in this study are obtained through the CRIOS-PATSTAT ${ }^{4}$ database, which contains standardised and cleansed information on all patent applications made at the European Patent Office (EPO) since its inception. Among these, the most relevant to our study are priority date, International Patent Classification (IPC) indicating the specific technological class of the patent and disambiguated applicant data including name and NUTS2 level location of applicants. The database is also used to collect information on all forward and backward EPO to EPO citations for all the patents analysed. With respect to the technological classification of patents, we adopt the reclassification of the IPC constituted

\footnotetext{
${ }^{3}$ The priority date refers to the year of worldwide first filing. Being the first date in the application process, this data can be considered as the closest to the date of invention.

${ }^{4}$ The CRIOS-PATSTAT database is developed and maintained by Bocconi University, and is based on the raw information available in the PATSTAT database, extracted by the EPO from its master documentation database (DOCDB). For a detailed description, see Coffano and Tarasconi (2014).
} 
by 30 different technological classes ${ }^{5}$ developed by Fraunhofer Gesellschaft-ISI (Karlsruhe), Institut National de la Propriété Industrielle (INPI, Paris) and Observatoire des Sciences and des Techniques (OST, Paris).

The strengths and weaknesses of patent data are well-known (see Griliches, 1990; Archibugi and Pianta, 1996): they offer a wide coverage of innovative activity in almost all technological sectors and fine-grained information on the technological characteristics of the patented invention and the patent applicants, whilst also ensuring the presence of a significant inventive step. Thus, despite the drawbacks that not all inventions are patented and the variance in the value of patents, they are used extensively within the literature on technological change, and provide an effective representation of regional innovative activities (Acs et al, 2002).

\subsection{Econometric model}

In order to test our hypotheses, we model firms' technological entry per 1 million people as a function of the degree of regional technological diversification at the NUTS2 level together with measures of technological opportunities, regional knowledge stock and academic research. A set of control variables to account for the socio-economic characteristics of the specific regions is included. Using panel data models, we can formally define our empirical specification as follows:

$$
\begin{aligned}
\ln (\text { TECH_ENTRY })_{\mathrm{it}}= & \alpha+\beta_{1} \text { REGIODIV }_{\mathrm{it}-1}+\beta_{2} \mathrm{R}_{-} \mathrm{TECHOPP} \\
& +\beta_{4} \ln \left(\beta_{3} \ln \ln \left(\mathrm{R} \_\mathrm{STOCK}\right)_{\mathrm{it}-1}\right. \\
& +\beta_{7}(\mathrm{HRST})_{\mathrm{it}-1}+\delta_{\mathrm{i}-1}+\varepsilon_{\mathrm{it}}
\end{aligned}
$$

\footnotetext{
${ }^{5}$ See Table A.1 in the Appendix for a detailed list of the technological classes. The IPC reclassification adopted has been used extensively in previous studies based on EPO patent data. See, for example, Breschi et al (2003) and Leten et al (2007).
} 
where REGIODIV is the index of regional technological diversification; R_TECHOPP is a measure of the technological opportunities in the region; R_STOCK is the regional knowledge stock; ACAD_CIT is the number of forward citations ${ }^{6}$ received by patents of public research institutions; GDP is the GDP per capita; POPDENS is the population density and HRST is the employment in science and technology related sectors. Finally, $\delta_{\mathrm{i}}$ represents the unobserved time-invariant region-specific effect and $\varepsilon_{\mathrm{it}}$ is the disturbance.

In the analysis, we first estimate our model with standard fixed effects (FE) regression. To further corroborate our findings, we also make use of Generalised Estimating Equations (GEE), first proposed by Liang and Zeger (1986). GEE models ${ }^{7}$ can be seen as an extension of generalized linear models (GLMs) for situations where the data follow a panel structure, in that they allow taking into consideration the correlated nature of the data within clusters or different levels exploiting both within and between variation (Hardin and Hilbe, 2013). The main difference between GEEs and more traditional conditional or subject-specific methods is that GEE estimate population-averaged models, also called marginal models, as they describe changes in the population mean for a given change in the covariates of interest.

\subsubsection{Dependent variable}

This study focuses on the cohort of new innovating companies as these play a central role in generating turbulence and dynamism in the innovation activity of regions, and constitute a fundamental element in the analysis of technological change. In this sense, the analytical perspective followed in the paper differs significantly from studies on new firm

\footnotetext{
${ }^{6}$ ACAD_CIT is expressed in terms of forward citations, as these have been argued to indicate the technological importance of inventions (Trajtenberg, 1990, Hall et al, 2005).

${ }^{7}$ One of the main strengths of GEEs is a consistent and unbiased estimation despite possible misspecification of the correlation structure (Hardin and Hilbe, 2013). In this study, the exchangeable correlation structure was selected following the quasilikelihood independence criterion (QIC). See Pan (2001).
} 
creation. As Malerba and Orsenigo (1999) point out, new innovators are not necessarily new firms, and some of them may have been economically active for some time before engaging in innovation activities leading to a positive patenting activity. At the same time, not all newly founded firms are necessarily innovators. In fact, only a small fraction is created with the launch of an innovation (See Audretsch, 1997).

We capture the presence of new innovators following the approach proposed by Malerba and Orsenigo (1999), and define the dependent variable TECH_ENTRY as the rate of firms' technological entry for each NUTS2 region, defined by those firms which are granted a patented innovation for the first time ${ }^{8}$. To account for the variance in the dimension of NUTS2 regions, we weight the number of new innovators with a dimensional variable (Lee et al, 2004). Thus, we define the dependent variable TECH_ENTRY as the rate of companies introducing a patented innovation for the first time per 1 million people.

\subsubsection{Independent variables}

The key explanatory variable in the model for testing our first hypothesis is represented by the degree of technological diversification at the regional level, REGIODIV. This variable is introduced to test the hypothesis that regions that are more technologically diverse might benefit from greater and broader 'combinative' opportunities for technological change (Kogut and Zander, 1992), leading to an increased rate of new innovative companies ${ }^{9}$. In particular, REGIODIV is constructed as an index which is based on a measure of technological dispersion calculated as the inverse of the Herfindahl index, confronting patents for each IPC technological class against the total number of patent of a given region. Using

\footnotetext{
${ }^{8}$ While the time frame for our analysis is limited by the economic data available from Eurostat, the full coverage for EPO applications provided by the CRIOS-PATSTAT allows us to take into account the whole patenting history of all patent applicants.

${ }_{9}^{9}$ Our measure of regional technological diversification focuses on the combinatorial nature of invention and does not reflect other qualities of diversity, such as regional vertical differentiation (Giovannetti, 2000). Albeit interesting, these are outside the scope of the paper.
} 
the bias correction indicated by Hall (2005) to account for observations with few patents per year, the index is formally defined as follows:

$$
R E G I O D I V_{r t}=\frac{N_{r t}}{N_{r t}-1}\left(1-\sum_{k=1}^{K}\left(\frac{N_{r t, k}}{N_{r t}}\right)^{2}\right)
$$

where $\mathrm{N}_{\mathrm{rt}}$ is the total number of patents for the $\mathrm{r}^{\text {th }}$ region in a given year $\mathrm{t}$, while $\mathrm{k}$ represents the specific IPC category of patents in the region and $\mathrm{K}$ is the total number of technological classes present in the region.

To provide further evidence for our first hypothesis, we specify an additional measure of regional technological diversification, labelled REGIODIV_W, which explicitly models the technological coherence across different IPC classes. Following Breschi et al (2003), we use the co-occurrence of patents' classification codes to calculate the cosine index $\mathrm{C}_{\mathrm{ij}}$ of technological relatedness for each pair of IPC classes. REGIODIV_W is then obtained using the resulting indexes as weights to calculate the weighted-average-relatedness (WAR) of regional technological activities (For the complete methodology see Ejermo, 2005).

To test our second hypothesis, we make use of patent-based indexes from the literature on technological change. Firstly, R_TECHOPP, represents regions' technological opportunities. This variable is constructed by applying the approach introduced by Patel and Pavitt (1998) and Corradini et al (2015). Such variable is defined as the change in the number of patents invented in the region in time $\mathrm{t}$ with respect to time $\mathrm{t}-1$, reflecting the dynamics of the innovation activity in the region.

Secondly, we control for the regional accumulated knowledge generated by previous innovative activities using the average knowledge stock of applicants (R_KSTOCK) for each region, as follows: 


$$
R_{-} \text {KSTOCK }_{r t}=\frac{1}{N r} \sum_{n r=1}^{N r}\left(P_{n r t}+(1-\delta) \text { SSTOCK }_{n r t-1}\right)
$$

where $P_{n r t}$ represents the number of patents for each $n$ company in region $r$ at the beginning of year $\mathrm{t}$ and $\delta$ is the depreciation rate, which is usually assumed to be $15 \%$ (Hall et al, $2005)^{10}$. Thus, the index R_KSTOCK is calculated as the average value at the regional level of single firms' knowledge stock. This variable enters the equation after being logtransformed.

Finally, we control for the innovation characteristics of regions related to the impact of academic research. We take into account this effect by introducing the variable ACAD_CIT, which is defined as the total number of forward citations ${ }^{11}$ received by patents of public research institutions in the region.

The second set of variables captures relevant regional socio-economic characteristics. Firstly, we include regions' GDP per capita; such variable is traditionally used in order to account for the size of the capital stock in the region. Secondly, we also include the variable POPDENS to control for the population density, defined as inhabitants per square kilometre, within each NUTS2 region. As Audretsch et al (2010) suggest, this density measure may be used to assess the impact of agglomeration economies. Both variables enter the model after being log-transformed. Thirdly, we introduce the variable HRST to capture the level of technological capabilities in the human capital of a region, expressed as the share of highly qualified employees. This refers to the percentage on active population of the human

\footnotetext{
${ }^{10}$ Given that our database contains information on all patent applications, we do not need to account for the effect of missing initial conditions.

${ }^{11}$ ACAD_CIT is expressed in terms of forward citations, as these have been argued to indicate the technological importance of inventions (Trajtenberg, 1990, Hall et al, 2005).
} 
resources employed in science and technology sectors. Finally, time and country dummies ${ }^{12}$ are included.

To take into account possible spillover effects from near regions, we also introduce spatial lags for the measures of technological opportunities and regional GDP calculated following the accessibility index proposed by Rodríguez-Pose and Crescenzi (2008):

$$
A_{i}=\sum_{j} g\left(r_{j}\right) f\left(c_{i j}\right)
$$

where $\mathrm{A}_{\mathrm{i}}$ is the accessibility of region $i, \mathrm{r}_{\mathrm{j}}$ is the activity $\mathrm{R}$ to be reached in region $j$ and $c_{i j}$ is the inverse of the bilateral road time-distance between regions $i$ and $j$. This index allows to avoid exogenously defined cut-off points for spatial lags, while the use of driving times provides a more realistic proxy for real-world interactions across space.

\section{Results and discussion}

\subsection{Descriptive statistics}

To offer an overview of the rate of technological entry across NUTS2 regions, we map the average values for TECH_ENTRY across 1997 and 2006 in Figure 1, which illustrates the significant variation of firms' technological entry across regions and countries. In particular, we observe that higher values for TECH_ENTRY are found in the Netherlands and the southern regions of Germany, Sweden and the UK, as well as in the north-east of Italy. Overall, technological entry seems to be more intense in regions commonly associated with higher levels of innovation, entrepreneurial activity and GDP per capita.

\footnotetext{
${ }^{12}$ Country dummies are included for the GEE model only, as FE models cannot be used to estimate timeinvariant variables.
} 
We start our analysis with the descriptive statistics and correlation matrix for our independent variables as reported in Tables 1 and 2. It is worth observing that the mean value for our main variable REGIODIV is relatively high, with a small standard deviation. This indicates that the observed NUTS2 regions are likely to be characterised by a wide diversity of technological activity and technological specialisation is a rare occurrence (Table 1). This is also shown in Figure 2, reporting average values for REGIODIV across NUTS2 regions. Second, while the average value for technological opportunities (R_TECHOPP) is low, at 0.13 , its standard deviation is high. This confirms that some regions are much more dynamic in terms of innovative output than others.

Figure 1: Firms' technological entry per NUTS2 regions (Average value 1997-2006).

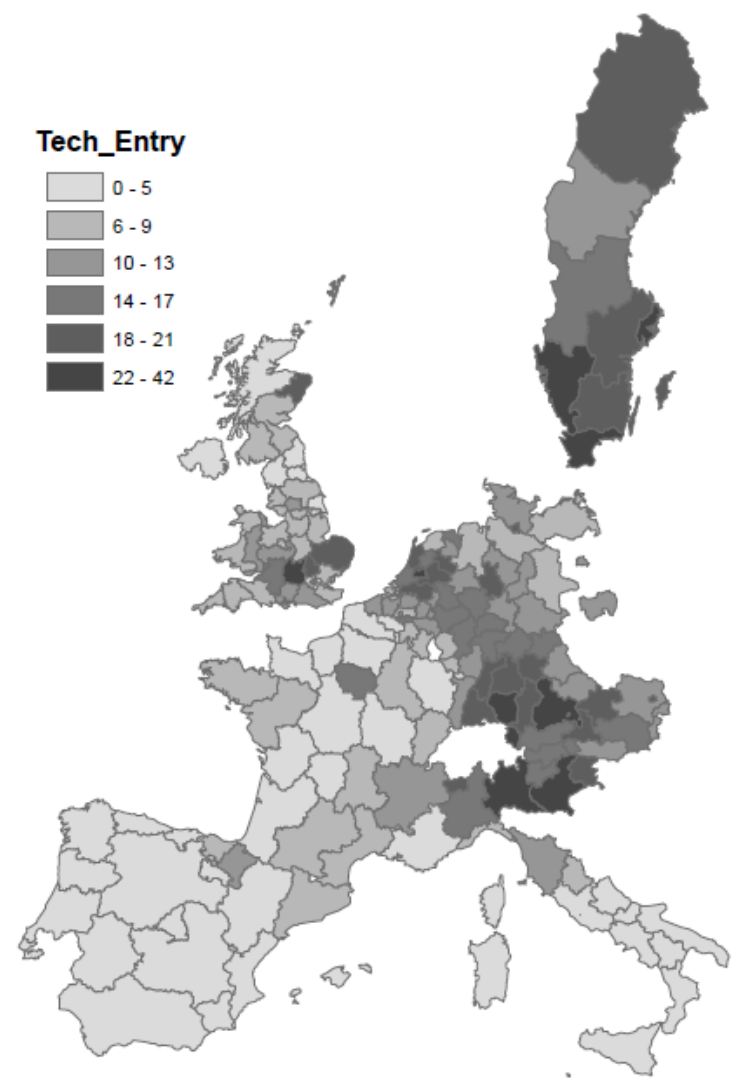


Figure 2: Technological diversification per NUTS2 regions (Average value 1997-2006).

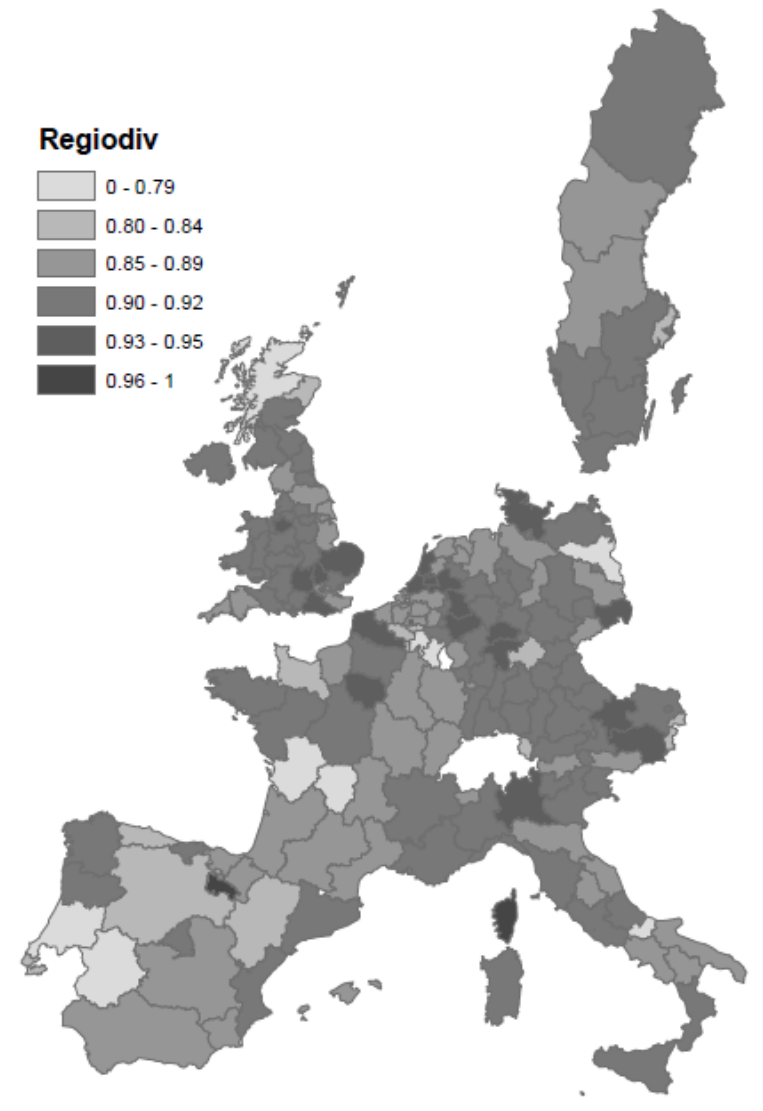

Interesting findings are also reported in the correlation matrix presented in Table 2. As one would expect, there is a significant correlation across economic variables such as GDP, population density (POPDENS) and employees in science and technology sectors (HRST), as well as between these variables and regions' patent stock (R_KSTOCK). This reflects the relationship between R\&D activity and GDP, namely the location of high-tech companies in densely populated areas.

When we consider the other innovation-based variables in Table 2, we observe that TECH_ENTRY is also correlated to the previous variables reflecting high R\&D activity and GDP. The correlation with REGIODIV, although positive at 0.242 , is significantly lower. 
Finally, we note that regions characterised by higher impact of public research seem to be more likely to also present higher levels of accumulated knowledge stock. This finding suggests that companies with a significant output of innovative activity tend to be located close to important academic centres.

Table 1: Descriptive statistics

\begin{tabular}{lccccccc}
\hline & Obs. & Mean & $\begin{array}{c}\text { St. } \\
\text { Dev. }\end{array}$ & Median & Max & Min & VIF \\
\hline InTECH_ENTRY & 1627 & 2.15 & 0.86 & 2.30 & 3.88 & -1.60 & 2.11 \\
REGIODIV & 1723 & 0.89 & 0.07 & 0.91 & 1 & 0 & 1.18 \\
REGIODIV_W & 1686 & 0.82 & 0.13 & 0.87 & 0.91 & 0 & 2.16 \\
R_TECHOPP & 1713 & 0.13 & 0.52 & 0.05 & 9 & -0.88 & 1.04 \\
InR_KSTOCK & 1741 & 7.23 & 3.13 & 6.94 & 17.05 & 0 & 2.17 \\
InACAD_CIT & 1741 & 1.01 & 1.33 & 0 & 6.7 & 0 & 1.55 \\
InGDP & 1561 & 10.05 & 0.28 & 10.06 & 11.39 & 8.99 & 2.58 \\
InPODENS & 1547 & 5.29 & 1.17 & 5.24 & 9.14 & 1.19 & 1.50 \\
HRST & 1536 & 34.88 & 7.28 & 34.85 & 58.90 & 11.10 & 2.25 \\
\hline
\end{tabular}

Table 2: Correlation matrix

\begin{tabular}{lccccccccc}
\hline & 1 & 2 & 3 & 4 & 5 & 6 & 7 & 8 & 9 \\
\hline InTECH_ENTRY & 1 & & & & & & & & \\
REGIODIV & 0.26 & 1 & & & & & & & \\
REGIODIV_W & 0.56 & 0.45 & 1 & & & & & & \\
R_TECHOPP & -0.08 & -0.08 & -0.17 & 1 & & & & & \\
InR_KSTOCK & 0.56 & 0.13 & 0.58 & -0.15 & 1 & & & & \\
InACAD_CIT & 0.29 & 0.27 & 0.30 & -0.04 & 0.49 & 1 & & & \\
InGDP & 0.63 & 0.20 & 0.45 & -0.18 & 0.60 & 0.33 & 1 & & \\
InPODENS & 0.18 & 0.26 & 0.25 & -0.06 & 0.42 & 0.44 & 0.39 & 1 & \\
HRST & 0.55 & 0.12 & 0.36 & -0.13 & 0.57 & 0.42 & 0.69 & 0.40 & 1 \\
\hline All correlations are significant at the .05 level & & & & & & & &
\end{tabular}

\subsection{Regression analysis and discussion}

In Table 3, we report the coefficients for our model using fixed effects (FE) and GEE estimation. Looking at the estimates for our main variable of interest REGIODIV, we observe a positive and statistically significant coefficient for both FE and GEE models, pointing to a 
positive effect exerted by increasing levels of technological diversification at the NUTS2 regional level on the rate of new innovating companies in the area. This supports our first hypothesis that increasing technological diversification embedded within the region may conduct to greater and broader 'combinative' opportunities for technological change resulting in a higher rate of firms' technological entry. These findings are robust to the alternative index of diversification REGIODIV_W accounting for the relatedness across different technologies.

With respect to our second hypothesis on the role of technological opportunities and the accumulated knowledge stock in the region, we find that both variables R_TECHOPP and R_STOCK have a positive and significant effect on TECH_ENTRY, although the coefficient for R_STOCK is not significant in the FE models with REGIODIV_W (Columns 2 and 4). Higher opportunity conditions, measured in terms of increasing patent rates, have usually been analysed with respect to widening patterns of innovation at the technological level. In our model, they reflect the innovation dynamics at the NUTS2 level, suggesting that regions with higher rates of innovative output provide fertile ground for new ideas, leading to the creation of new innovative companies. Similarly to other types of knowledge spillovers, this effect seems to dissipate with distance, as R_TECHOPP_sp is found to be not significant across all model specifications.

The positive sign of the variable R_STOCK confirms that regions characterised by companies with a higher stock of knowledge, described in terms of accumulated patents, are more likely to facilitate technological entry. This finding points to the presence of spill-over effects that may originate from the concentration of innovative activities. This is in line with the knowledge-spillover theory of entrepreneurship, where entrepreneurial technological opportunities result from the accumulated stock of knowledge generated by the R\&D activity of incumbent firms which is not commercialised (Audretsch et al, 2006; Acs et al, 2009). 
The impact of academic research is also found to be positive and significant in all model specifications, as suggested by the coefficient for ACAD_CIT. This further confirms the role played by public research in fostering the creation of new innovative companies through knowledge spillovers and network effects (Cooke, 2002; Rodríguez-Pose and Refolo, 2003).

Looking at the set of economic variables, FE estimates for both GDP and population density (POPDENS) are found to be not statistically significant. Conversely, GEE estimates indicate an expected positive effect for GDP, which is reinforced by spillover effects from neighbouring regions, whereas POPDENS has a negative coefficient.

HRST is found to have a positive and significant effect on TECH_ENTRY in both FE and GEE models. This indicates that regions characterised by human capital with higher levels of technological capabilities are more likely to generate new ideas and knowledge, resulting in higher firms' technological entry. At the same time, as suggested by Audretsch et al (2010), highly qualified employees can be thought of having a particularly high propensity to found new enterprises. 
Table 3: Fixed effects and GEE estimates

\begin{tabular}{|c|c|c|c|c|c|c|c|c|}
\hline \multirow[t]{2}{*}{ InTECH_ENTRY } & \multicolumn{4}{|c|}{ Fixed-effects } & \multicolumn{4}{|c|}{ GEE } \\
\hline & (1) & (2) & (3) & (4) & (5) & (6) & $(7)$ & $(8)$ \\
\hline REGIODIV & $\begin{array}{l}0.383^{*} \\
(0.197)\end{array}$ & & $\begin{array}{l}0.440^{* *} \\
(0.194)\end{array}$ & & $\begin{array}{c}0.684^{\star * *} \\
(0.196)\end{array}$ & & $\begin{array}{c}0.751^{* * *} \\
(0.197)\end{array}$ & \\
\hline REGIODIV_W & & $\begin{array}{c}0.395^{* * *} \\
(0.134)\end{array}$ & & $\begin{array}{c}0.379^{* * *} \\
(0.129)\end{array}$ & & $\begin{array}{c}0.619^{* * *} \\
(0.133)\end{array}$ & & $\begin{array}{c}0.551^{* * *} \\
(0.124)\end{array}$ \\
\hline R_TECHOPP & $\begin{array}{c}0.346^{* * *} \\
(0.032)\end{array}$ & $\begin{array}{c}0.358^{* * *} \\
(0.031)\end{array}$ & $\begin{array}{c}0.353^{\star * *} \\
(0.035)\end{array}$ & $\begin{array}{c}0.361^{* * *} \\
(0.035)\end{array}$ & $\begin{array}{c}0.342^{* * *} \\
(0.031)\end{array}$ & $\begin{array}{c}0.374^{\star \star *} \\
(0.034)\end{array}$ & $\begin{array}{c}0.350^{* * *} \\
(0.035)\end{array}$ & $\begin{array}{c}0.375^{\star \star *} \\
(0.038)\end{array}$ \\
\hline R_TECHOPP_sp & $\begin{array}{l}-0.186 \\
(0.283)\end{array}$ & $\begin{array}{c}-0.186 \\
(0.284)\end{array}$ & $\begin{array}{c}-0.317 \\
(0.286)\end{array}$ & $\begin{array}{l}-0.320 \\
(0.287)\end{array}$ & $\begin{array}{c}-0.213 \\
(0.277)\end{array}$ & $\begin{array}{l}-0.246 \\
(0.281)\end{array}$ & $\begin{array}{c}-0.302 \\
(0.284)\end{array}$ & $\begin{array}{l}-0.345 \\
(0.287)\end{array}$ \\
\hline InR_KSTOCK & $\begin{array}{l}0.036^{*} \\
(0.020)\end{array}$ & $\begin{array}{c}0.020 \\
(0.020)\end{array}$ & $\begin{array}{l}0.028^{\star} \\
(0.020)\end{array}$ & $\begin{array}{c}0.010 \\
(0.020)\end{array}$ & $\begin{array}{c}0.063^{\star * *} \\
(0.012)\end{array}$ & $\begin{array}{c}0.042^{\star \star \star} \\
(0.012)\end{array}$ & $\begin{array}{c}0.058^{* * *} \\
(0.013)\end{array}$ & $\begin{array}{c}0.038^{* * *} \\
(0.012)\end{array}$ \\
\hline InACAD_CIT & $\begin{array}{l}0.030^{* *} \\
(0.012)\end{array}$ & $\begin{array}{l}0.030^{* *} \\
(0.012)\end{array}$ & $\begin{array}{c}0.034^{* * *} \\
(0.012)\end{array}$ & $\begin{array}{c}0.034^{* * *} \\
(0.012)\end{array}$ & $\begin{array}{l}0.024^{\star *} \\
(0.011)\end{array}$ & $\begin{array}{l}0.027^{* *} \\
(0.011)\end{array}$ & $\begin{array}{l}0.023^{\star *} \\
(0.011)\end{array}$ & $\begin{array}{l}0.027^{* *} \\
(0.011)\end{array}$ \\
\hline InGDP & $\begin{array}{c}0.264 \\
(0.219)\end{array}$ & $\begin{array}{c}0.276 \\
(0.215)\end{array}$ & $\begin{array}{c}0.219 \\
(0.220)\end{array}$ & $\begin{array}{c}0.241 \\
(0.217)\end{array}$ & $\begin{array}{c}1.241^{\star * *} \\
(0.158)\end{array}$ & $\begin{array}{l}1.258^{\star \star *} \\
(0.156)\end{array}$ & $\begin{array}{c}0.945^{\star * *} \\
(0.161)\end{array}$ & $\begin{array}{c}0.998^{* * *} \\
(0.164)\end{array}$ \\
\hline InGDP_sp & $\begin{array}{l}0.119^{* *} \\
(0.059)\end{array}$ & $\begin{array}{l}0.124^{* *} \\
(0.058)\end{array}$ & $\begin{array}{l}0.139^{\star *} \\
(0.059)\end{array}$ & $\begin{array}{l}0.145^{\star *} \\
(0.059)\end{array}$ & $\begin{array}{c}0.168^{\star * *} \\
(0.045)\end{array}$ & $\begin{array}{c}0.177^{\star \star *} \\
(0.045)\end{array}$ & $\begin{array}{c}0.162^{* * *} \\
(0.044)\end{array}$ & $\begin{array}{c}0.171^{\star * *} \\
(0.044)\end{array}$ \\
\hline InPOPDENS & $\begin{array}{c}0.411 \\
(0.471)\end{array}$ & $\begin{array}{c}0.423 \\
(0.475)\end{array}$ & $\begin{array}{c}-0.101 \\
(0.491)\end{array}$ & $\begin{array}{l}-0.092 \\
(0.503)\end{array}$ & $\begin{array}{l}-0.091^{* *} \\
(0.041)\end{array}$ & $\begin{array}{l}-0.081^{\star *} \\
(0.038)\end{array}$ & $\begin{array}{c}-0.084^{\star *} \\
(0.040)\end{array}$ & $\begin{array}{l}-0.075^{\star} \\
(0.039)\end{array}$ \\
\hline HRST & & & $\begin{array}{l}0.012^{*} \\
(0.007)\end{array}$ & $\begin{array}{l}0.012^{*} \\
(0.007)\end{array}$ & & & $\begin{array}{c}0.016^{\star * *} \\
(0.006)\end{array}$ & $\begin{array}{c}0.015^{\star * *} \\
(0.005)\end{array}$ \\
\hline _cons & $\begin{array}{c}-4.205 \\
(3.285)\end{array}$ & $\begin{array}{c}-4.277 \\
(3.280)\end{array}$ & $\begin{array}{l}-1.613 \\
(3.307)\end{array}$ & $\begin{array}{l}-1.702 \\
(3.373)\end{array}$ & $\begin{array}{c}-12.003^{\star \star \star} \\
(1.574)\end{array}$ & $\begin{array}{c}-12.065^{\star * *} \\
(1.533)\end{array}$ & $\begin{array}{c}-9.611^{\star * *} \\
(1.576)\end{array}$ & $\begin{array}{c}-9.894^{\star * *} \\
(1.578)\end{array}$ \\
\hline $\mathrm{N}$ & 1349 & 1338 & 1227 & 1216 & 1349 & 1338 & 1227 & 1216 \\
\hline Country dummies & No & No & No & No & Yes & Yes & Yes & Yes \\
\hline Time dummies & Yes & Yes & Yes & Yes & Yes & Yes & Yes & Yes \\
\hline
\end{tabular}

Standard errors in parentheses

$* * * \mathrm{p}<0.01 * * \mathrm{p}<0.05 * \mathrm{p}<0.10$ 


\section{Conclusions}

In this paper, we have looked at the role played by technological diversification at the regional level in fostering firms' technological entry using economic and patent data over the period of time between 1997 and 2006 for ten EU countries, that is, Austria, Belgium, Germany, Spain, France, Italy, the Netherlands, Portugal, Sweden and the UK.

The analysis of firms' technological entry is a central element in the literature on industry and regional dynamics, as these firms play a crucial role in defining widening patterns of technological change that are essential for the development of novel technological paradigms and new industry creation (Schumpeter, 1934; Malerba and Orsenigo, 1999), exerting an important function in fostering economic resilience in regions. This paper contributes to these streams of research providing empirical evidence of the positive effect that regional technological diversification play in enhancing regional 'combinatorial' opportunities fostering the emergence of new innovators.

Our findings support the argument that connections and communication across actors characterised by different technological competencies are crucial in the development of new technological combinations. The tacit nature of knowledge suggests that such novel combinations are more complex to envision and realise when some elements are not available in the region. Accordingly, our findings point to the importance of regional embeddedness to activate social interactions which enhance the opportunities for innovators embodying diverse knowledge competences to search, share and connect previously unrelated ideas. Through such processes, novel combinations emerge fostering the development of new innovating firms. Hence, regional diversification is shown to play a crucial role in prompting new technological trajectories, enriching industry dynamics.

Such combinatorial processes can be further reinforced by other characteristics of regional innovation systems. In this sense, we observe a positive effect for regional 
technological opportunities and the accumulated stock of knowledge, reflecting the role of combinative elements and spillover effects originating from innovative activities among incumbent firms. Similarly, our results also confirm the contribution of academic research in creating knowledge-spillovers supporting the development of new innovative companies.

Our findings point to some important policy recommendations. In particular, policies focusing exclusively on the benefits of specialisation may lead towards a lower resilience of regional innovation systems and lock-in effects in the presence of novel technological trajectories. Conversely, initiatives encouraging the presence of a broader regional technological base may benefit from dense inter-sector cross-fertilisation and greater regional innovative dynamism thanks to the more pronounced spawning of new innovative firms.

\section{References}

Acs Z, Braunerhjelm P, Audretsch D B, Carlsson B, 2009, “The knowledge spillover theory of entrepreneurship" Small Business Economics 32 15-30

Acs, Z, Anselin L, Varga A, 2002, "Patents and innovation counts as measures of regional production of new knowledge" Research policy 31 1069-1085

Anselin L, Varga A, Acs Z, 1997, "Local Geographic Spillovers between University Research and High Technology Innovations" Journal of Urban Economics 42(3) 422448

Antonelli C, 2000, "Collective knowledge communication and innovation: the evidence of technological districts" Regional studies 34(6) 535-547 
Archibugi D, Pianta M, 1996, "Measuring technological change through patents and innovation surveys" Technovation 16 451-468

Armington C, Acs Z J, 2002, “The Determinants of Regional Variation in New Firm Formation" Regional Studies 36 33-45

Arthur W B, 2007, “The structure of invention” Research Policy 36 274-287

Audretsch D, 1997, "Technological regimes, industrial demography and the evolution of industrial structures" Industrial and Corporate Change 6 49-82

Audretsch D B, Keilbach M, Lehmann E, 2006, Entrepreneurship and economic growth (Oxford University Press, New York)

Audretsch D B, Vivarelli M, 1996, "Firm size and R\&D spillovers: evidence from Italy" Small Business Economics 8 249-258

Audretsch D, Dohse D, Niebuhr A, 2010, “Cultural diversity and entrepreneurship: a regional analysis for Germany" The Annals of Regional Science 45(1) 55-85

Beaudry C, Schiffauerova A, 2009, "Who's right, Marshall or Jacobs? The localization versus urbanization debate" Research Policy 38 318-337

Beaudry, C, Breschi, S, 2003, “Are firms in clusters really more innovative?" Economics of Innovation and New Technology 12 325-342

Bellandi M, 1996, "Innovation and Change in the Marshallian Industrial District" European Planning Studies 4(3) 357-368

Boschma R, Minondo A, Navarro M, 2012, "Related variety and regional growth in Spain" Papers in Regional Science 91(2) 242-257

Breschi S, Lissoni F, Malerba F, 2003, "Knowledge-relatedness in firm technological diversification" Research Policy 32 69-87

Breschi S, Malerba F, Orsenigo L, 2000, “Technological regimes and Schumpeterian patterns of innovation" The Economic Journal $110388-410$ 
Camagni R., 1991, Innovation networks. Spatial perspectives (Bellhaven Press, London/New York)

Castaldi C, Frenken K, Los B, 2014, "Related Variety, Unrelated Variety and Technological Breakthroughs: an analysis of US state-level patenting" Regional Studies (forthcoming) Coffano M, Tarasconi G, 2014, "CRIOS - Patstat Database: Sources, Contents and Access Rules" Center for Research on Innovation, Organization and Strategy, CRIOS Working Paper $n .1$

Cooke P, 2001, "Regional Innovation Systems, Clusters, and the Knowledge Economy" Industrial and Corporate Change 10(4) 945-974

Cooke P, 2002, "Regional Innovation Systems: General Findings and Some New Evidence from Biotechnology Clusters" The Journal of Technology Transfer 27(1) 133-145

Cooke P, Morgan K, 1998, The associational economy. Firms, regions, and innovation (Oxford University Press, Oxford)

Cooke P, Uranga M G, Etxebarria G, 1998, "Regional systems of innovation: an evolutionary perspective" Environment and planning A 30(9) 1563-1584

Corradini C, Battisti G, Demirel P, 2015, "Serial innovators in the UK: does size matter?" Industrial and Corporate Change (forthcoming)

Desrochers P, 2001, "Local diversity, Human creativity, and technological innovation" Growth and Change 32(3) 369-394

Ejermo O, 2005, “Technological diversity and Jacobs' externality hypothesis revisited" Growth and Change 36 167-195

Etzkowitz H, 2008, The Triple Helix: University-Industry-Government Innovation in Action (Routledge)

Feldman M, Audretsch D, 1999, "Innovations in cities: science-based diversity, specialization and localized monopoly" European Economic Review 43409 - 429 
Fleming L, 2001, "Recombinant Uncertainty in Technological Search” Management Science 47 117-132

Florida R, 2002, "Bohemia and economic geography" Journal of Economic Geography 2(1) $55-71$

Florida R, Gates G, 2003, "Technology and tolerance: the importance of diversity to hightechnology", The City as an Entertainment Machine Ed Ns Clark (Research in Urban Policy, Volume 9), Emerald Group Publishing Limited, 199-219

Frenken K, Van Oort F, Verburg T, 2007, "Related Variety, Unrelated Variety and Regional Economic Growth” Regional Studies 41 685-697

Giovannetti, E, 2000, "Technology Adoption and the Emergence of Regional Asymmetries" Journal of Industrial Economics 48(1) 71-102

Glaeser E L, Kallal H, Scheinkman J, Shleifer A, 1992, "Growth in cities" Journal of Political Economy 100 1126-1152

Granstrand, O, 1998, "Towards a Theory of the Technology-Based Firm" Research Policy 17 $465-489$

Gregersen B, Johnson B, 1997, "Learning economies, innovation systems and European integration" Regional studies 31(5) 479-490

Griliches Z, 1990, "Patent Statistics as Economic Indicators: A Survey" Journal of Economic Literature 28 1661-1707

Hall B H, 2005, "A Note on the Bias in Herfindahl-Type Measures Based on Count Data" Revue d'Économie Industrielle, Programme National Persée 110(1) 149-156

Hall B H, Jaffe A, Trajtenber M, 2005, "Market Value and Patent Citations" The RAND Journal of Economics 36(1) 16-38

Hardin J W, Hilbe J M, 2013, Generalized Estimating Equations, $2^{\text {nd }}$ Edition (Chapman and Hall) 
Howells J R, 2002, “Tacit knowledge, innovation and economic geography” Urban studies 39(5-6) 871-884

Jacobs J, 1969, The Economy of Cities (Vintage, New York)

Klepper S, 1996, "Entry, Exit, Growth, and Innovation over the Product Life Cycle" American Economic Review $\mathbf{8 6} 562-83$

Kogut B, Zander U, 1992, "Knowledge of the Firm, Combinative Capabilities, and the Replication of Technology" Organization Science 3, 393-397

Lee S Y, Florida R, Acs Z J, 2004, “Creativity and entrepreneurship: a regional analysis of new firm formation" Regional Studies 38 879-891

Leten B, Belderbos R, Van Looy B, 2007, “Technological Diversification, Coherence, and Performance of Firms" Journal of Product Innovation Management 24 567-579

Liang K, Zeger S, 1986, "Longitudinal Data Analysis Using Generalized Linear Models" Biometrika 73(1) 13-22

Malerba F, Orsenigo L, 1993, “Technological regimes and firm behaviour" Industrial and Corporate Change 2(1) 45-71

Malerba F, Orsenigo L, 1999, “Technological Entry, Exit and Survival: An Empirical Analysis of Patent Data" Research Policy 28 643-660

Marshall A, 1890, Principles of Economics (MacMillan, London)

Maurseth P, Verspagen B, 2002, "Knowledge spillovers in Europe. A patent citations analysis" Scandinavian Journal of Economics 104 531-545

Moreno R, Paci R, Usai S, 2005, "Spatial spillovers and innovation activity in European regions" Environment and Planning A 37(10) 1793-1812

Nelson R R, Winter S, 1982, An Evolutionary Theory of Economic Change (Belknap Press)

Pan W, 2001, "Akaike's information criterion in generalized estimating equations" Biometrics 57 120-125 
Patel P, Pavitt K, 1998, “The Wide (and Increasing) Spread of Technological Competencies in the World's Largest Firms: A Challenge to Conventional Wisdom" in The Dynamic Firm. The Role of Technology, Strategy, Organization, and Regions Eds A D Chandler, P Hageström, Ö Slölvell (Oxford: Oxford University Press)

Peter Hall (1998), Cities in Civilization: Culture, Technology, and Urban Order. London: Weidenfeld \& Nicolson; New York: Pantheon Books.

Rodríguez-Pose A, Crescenzi R, 2008, "Research and Development, Spillovers, Innovation Rodríguez-Pose A, Refolo M C, 2003, "The link between local production systems and public and university research in Italy" Environment and Planning A 35(8) 1477-1492

Rosenthal S, Strange W, 2003, "Geography, industrial organization, and agglomeration" The Review of Economics and Statistics 85 377-393

Schumpeter J A, 1934, The theory of economic development (Transaction Publishers)

Sonn J W, Storper M, 2008, "The increasing importance of geographical proximity in knowledge production: an analysis of US patent citations, 1975 - 1997" Environment and Planning A 40(5) 1020-1039

Storper M, 1995, "The resurgence of regional economies, ten years after: the region as a nexus of untraded interdependences" European Urban and Regional Studies 2 191-221

Storper M, 1997, The regional world (The Guilford Press, New York)

Storper, M, Venables A J, 2004, "Buzz: face-to-face contact and the urban economy" Journal of economic geography 4(4) 351-370

Systems, and the Genesis of Regional Growth in Europe" Regional Studies 42(1) 51-67

Trajtenberg M, 1990, "A Penny for Your Quotes: Patent Citations and the Value of Innovations" The Rand Journal of Economics 21 172-187

Winter S, 1984, "Technological competition in alternative technological regimes" Journal of Economic Behaviour and Organization 5 287-320. 


\section{APPENDIX}

Table A.1: International patent classification (IPC) technological classes

\begin{tabular}{|l|l|}
\hline \multicolumn{1}{|c|}{ IPC class code } & \\
\hline 1 & Technological class \\
2 & Alectrical engineering \\
3 & Audiovisual technology \\
4 & Telecommunications \\
5 & Information technology \\
6 & Semiconductors \\
7 & Optics \\
8 & Technologies for Control/Measures/Analysis \\
9 & Medical engineering \\
10 & Nuclear technology \\
11 & Organic chemistry \\
12 & Macromolecular chemistry \\
13 & Basic chemistry \\
14 & Surface technology \\
15 & Materials; Metallurgy \\
16 & Biotechnologies \\
17 & Pharmaceuticals; Cosmetics \\
18 & Agricultural and food products \\
19 & Technical processes (chemical, physical, mechanical) \\
20 & Handling; Printing \\
21 & Materials processing, textile, glass, paper \\
22 & Environmental technologies \\
23 & Agricultural and food apparatuses \\
25 & Machine tools \\
26 & Engines; Pumps; Turbines \\
28 & Thermal processes \\
30 & Mechanical elements \\
& Transport technology \\
& Space technology; Weapons \\
\hline & Consumer goods \\
\hline $29 i 1$ engineering \\
\hline
\end{tabular}

